
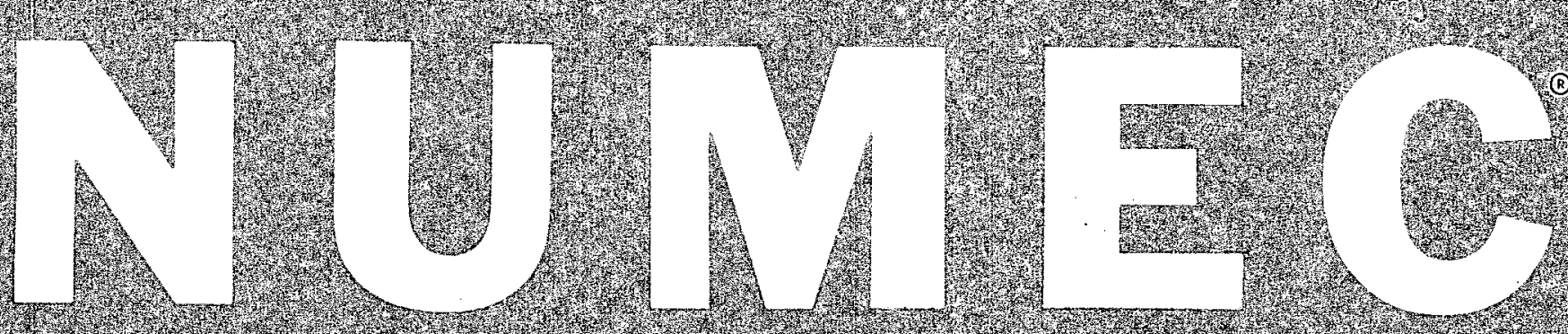

Nuelear Materials and Eq Elipment Corporation

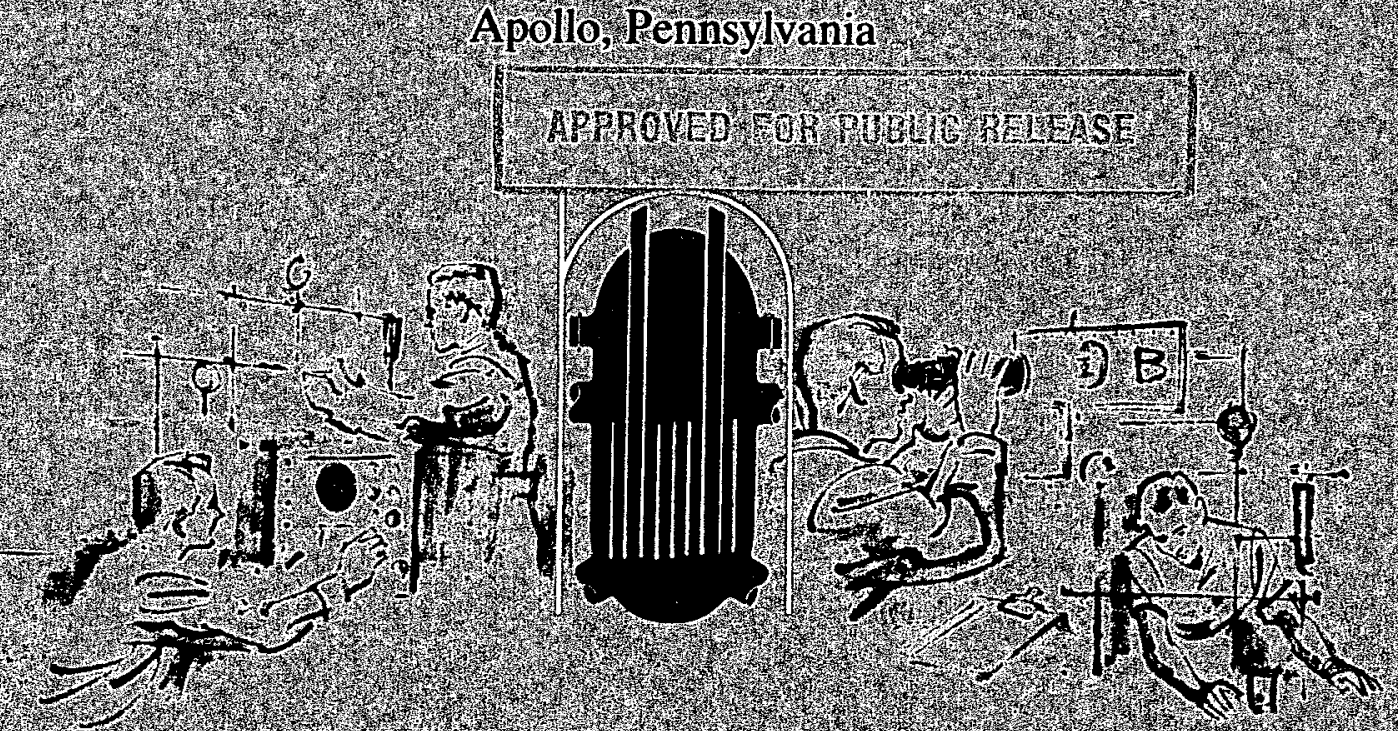




\section{DISCLAIMER}

This report was prepared as an account of work sponsored by an agency of the United States Government. Neither the United States Government nor any agency Thereof, nor any of their employees, makes any warranty, express or implied, or assumes any legal liability or responsibility for the accuracy, completeness, or usefulness of any information, apparatus, product, or process disclosed, or represents that its use would not infringe privately owned rights. Reference herein to any specific commercial product, process, or service by trade name, trademark, manufacturer, or otherwise does not necessarily constitute or imply its endorsement, recommendation, or favoring by the United States Government or any agency thereof. The views and opinions of authors expressed herein do not necessarily state or reflect those of the United States Government or any agency thereof. 


\section{DISCLAIMER}

Portions of this document may be illegible in electronic image products. Images are produced from the best available original document. 
NUNEC -2389.6

\title{
Sintering Behavior of Plutonium Dioxide
}

\author{
by \\ M. D. Houston \\ Plutonium Laboratory \\ Nuclear Materials and Equipment Corporation \\ Apollo, Pennsylvania
}

Work Performed Under AEC

Contract $\operatorname{AT}(30-1)=2389$

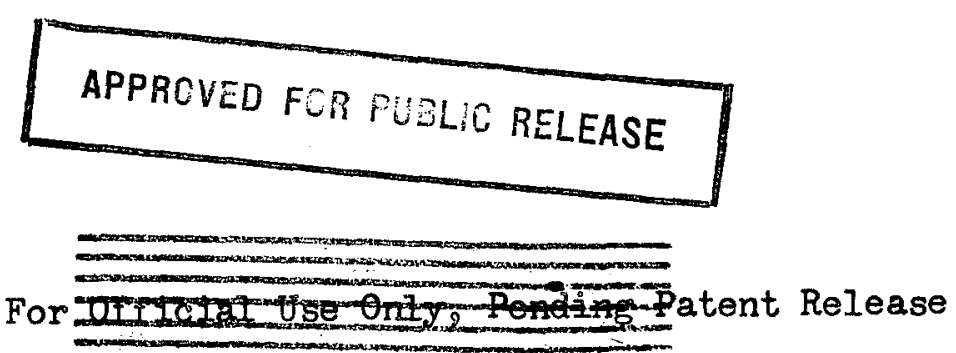


NUMEC $-2389-6$

\section{TABLE OF CONTENTS}

$\begin{array}{lc} & \text { Page } \\ \text { ABSTRACT } & 1 \\ \text { INTRODUCTION } & 2 \\ \text { EXPERIMENTAL PROCEDURE } & 4 \\ \text { RESULTS AND DISCUSSION } & 6 \\ \text { SUMMARY AND CONCLUSIONS } & 19 \\ \text { ACKNOWLEDGEMENTS } & 20 \\ \text { REFERENCES } & 21\end{array}$

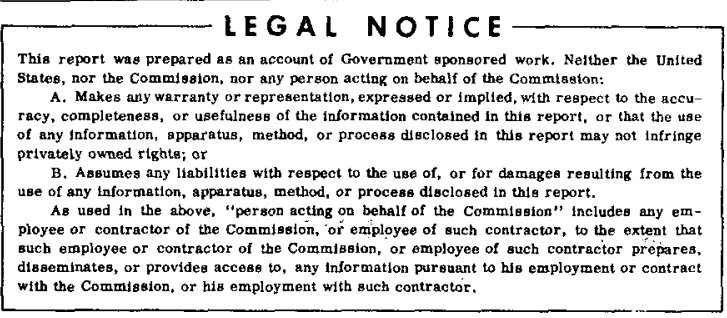


NUMEC $-2389-6$

\section{ABSTRACT}

Compacts of plutonium dioxide have been prepared and sintered in order to study the sinterability of $\mathrm{PuO}_{2}$ powders prepared by various routes, and further, to study the effect of controlled impurity additions.

The plutonium dioxide was prepared by precipitation from nitrate solution of oxalate, hydroxide, and peroxide and subsequent conversion. Some powders were also prepared by direct oxidation of plutonium metal and by direct denitration of plutonium nitrate solution. Sintering was performed at $1600^{\circ} \mathrm{C}$ in both a reducing atmosphere, $\mathrm{N}_{2} 6 \% \mathrm{H}_{2}$, and an oxidizing atmosphere, $\mathrm{O}_{2}$ 。

Generally, higher densities resulted from compacts sintered in oxygen as anticipated, since sintering in a reducing atmosphere tends towards the formation of lower density suboxides.

Sintered densities also tended to be higher for the oxalate derived material.

Controlled additions primarily of $\mathrm{Y}_{2} \mathrm{O}_{3}$ and 5 ro were studied as sintering aids. The results indicate that $5 r 0$ addition in the range of 0.4 to 1.0 mol percent has a pronounced beneficial effect in increasing sintered density。 
NUMEC $-2389-6$

INTRODUCTION

Of all the ceramic oxides, only a relatively few crystallize in the fluorite structure and the majority of these are of great interest for nuclear applications. This interest is based mainly on three favorable physical characteristics:

(1) a fairly high melting point: (2) good resistance toward radiation damage; and (3) crystallographic stability over a wide temperature range. These oxides when listed in order of increasing lattice parameter, Table $I_{2}$ appear to fall into three distinct groups: (1) fluorite structure possible by impurity stabilization (no other oxidation states) as with the smaller cations Zr and $\mathrm{Hf}_{9}$ (2) fluorite structure stable with the tetravalent cation representing the

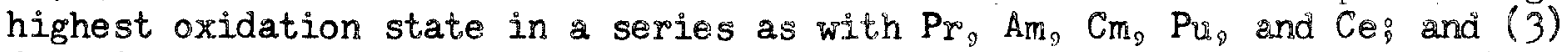
fluorite structure stable with the tetravalent eation representing the lowest or only oxidation state as with $\mathrm{Np}_{9} \mathrm{U}_{9} \mathrm{~Pa}_{9}$ and $\mathrm{Th}$ 。

An important area of ceramic fuel development is that concerned with one of these fluorite structural oxides, plutonium dioxide. While it is unlikely that pure $\mathrm{PuO}_{2}$ will be utilized as a commercial reactor fuel, a complete ceramic evaluation of this material is essential since fuel compositions based on $\mathrm{PuO}_{2}$ dispersed or dissolved in a fertile or an inert matrix will become of increasing importance. While most of the work to date has dealt with the $\mathrm{UO}_{2} \mathrm{PuO}_{2}$ system $(1,2,3,4,5,6)$, the investigations reported herein are limited to $\mathrm{P}_{2} \mathrm{O}_{2}$; in particular to:

(1) comparison of $\mathrm{PuO}_{2}$ powders prepared by various methods: (2) evaluation of sintering behavior under different atmospheric conditions: and (3) study of the effect of various impurity additions upor the sintering behavior. 
NUNEC - 2389-6

Table I

Properties of Fluorite Structured Oxides

\begin{tabular}{|c|c|c|c|c|c|}
\hline Compound & $\begin{array}{l}\text { Lattice } \\
\text { Congtant } \\
\quad \AA \\
\end{array}$ & $\begin{array}{l}\text { Cation } \\
\text { Radius } \\
\text { A }\end{array}$ & $\begin{array}{l}\text { Melting } \\
\text { Point } \\
\text { OC } \\
\end{array}$ & $\begin{array}{c}\text { Number of } \\
\text { Lower } \\
\text { Oxides } \\
\end{array}$ & $\begin{array}{l}\text { Number of } \\
\text { Higher } \\
\text { Oxides } \\
\end{array}$ \\
\hline $\begin{array}{l}\mathrm{ZrO}_{2} \\
\mathrm{HfO}_{2}\end{array}$ & $\begin{array}{l}5.07 \\
5.11\end{array}$ & $\begin{array}{l}0.79 \\
0.78\end{array}$ & $\begin{array}{l}2700 \\
2810\end{array}$ & $\begin{array}{l}\text { None } \\
\text { None }\end{array}$ & $\begin{array}{l}\text { None } \\
\text { None }\end{array}$ \\
\hline $\begin{array}{l}\mathrm{PrO}_{2} \\
\mathrm{CmO}_{2} \\
\mathrm{AmO}_{2} \\
\mathrm{PuO}_{2} \\
\mathrm{CeO}_{2}\end{array}$ & $\begin{array}{l}5.36 \\
5.37 \\
5.38 \\
5.39 \\
5.41\end{array}$ & $\begin{array}{l}0.92 \\
= \\
0.92 \\
0.93 \\
1.07\end{array}$ & $\begin{array}{c}= \\
2500 \\
2600\end{array}$ & $\begin{aligned} & 5 \\
& 1 \\
& 1 \\
& 2 \text { or } 3 \\
& 5\end{aligned}$ & $\begin{array}{l}\text { None } \\
\text { None } \\
\text { None } \\
\text { None } \\
\text { None }\end{array}$ \\
\hline $\begin{array}{l}\mathrm{NpO}_{2} \\
\mathrm{UO}_{2} \\
\mathrm{PaO}_{2} \\
\mathrm{ThO}_{2}\end{array}$ & $\begin{array}{l}5.42 \\
5.47 \\
5.50 \\
5.59\end{array}$ & $\begin{array}{l}0.95 \\
0.97 \\
0.98 \\
1.02\end{array}$ & $\begin{array}{c}\infty \\
2800 \\
3050\end{array}$ & $\begin{array}{l}\text { None } \\
\text { None } \\
\text { None } \\
\text { None }\end{array}$ & $\begin{array}{c}1 \\
3 \\
\text { None }\end{array}$ \\
\hline
\end{tabular}


NUNEC $-2389-6$

\section{EXPER IMENTAL PROCEDURE}

Plutonium dioxide can be prepared by (1) direct oxidation of plutonium metal in air or steam: (2) direct ignition of plutonium nitrate solution; or (3) preo cipitation from nitrate solution as the oxalate, peroxide, or hydroxide followed by calcination to the oxide. These studies concentrated on the use of material prepared by the precipitation processes. The process parameters and particie characteristics of the various powders prepared by precipitation are presented in Table II。

The sintering behavior of the various powders was studied by the use of compacted right cylindrical pellet's. The feed powders were compacted in hardened steel dies at pressures ranging from 10 to $40 \mathrm{TSI}$. An organic binder was never cono sidered for experimental evaluation because of the known reaction between $\mathrm{PrO}_{2}$ and carbon. A frim of stearic acid solution was used as a die and punch lubricant. The compacts were sintered at $1600^{\circ} \mathrm{C}$ in molybdenum boats under flowing ( $4 \mathrm{cth}$ ) nitrogen $6 \%$ hydrogen atmosphere or in platinum boats under flowing oxygen. The heating and cooling rates for all firings were approximately $350^{\circ} \mathrm{C}$ per hour。 No detrimental interaction between $\mathrm{PuO}_{2}$ and the boat materials was ever observed.

A number of pellet physical characteristics were determined subsequent to sintering. Geometric densities were calculated from the weight and external dimensions. The microstructures of mounted and polished sections were brought out by cathodic vacuum etching and examined with a Unitron metallographic unit using reflected light. Electrical resistance measurements were made at room temperature with a. Wheatstone bridge. High surface resistance on the oxide shapes was overcome by the application of liquid InoGa contacts. X-iray diffraction was used for phase identiflication and lattice parameter determination. 
NUMEC $-2389 \div 6$

Table II

Preparation Conditions and $\mathrm{PuO}_{2}$ Powder Characteristics

\begin{tabular}{|c|c|c|c|c|c|c|}
\hline $\begin{array}{c}\text { Batch } \\
\text { Designation }\end{array}$ & $\begin{array}{l}\text { Calcination } \\
\text { Temperature } \\
{ }_{\mathrm{O}} \mathrm{C} \\
\end{array}$ & $\begin{array}{c}\text { Calcination } \\
\text { Time } \\
\text { Minutes } \\
\end{array}$ & $\begin{array}{c}\text { Surface } \\
\text { Area } \\
M^{2} / \mathrm{gm} \\
\end{array}$ & $\begin{array}{l}\text { Bulk } \\
\text { Density } \\
\text { gm/cc }\end{array}$ & $\begin{array}{c}\text { Tap } \\
\text { Density } \\
\text { gm/ce }\end{array}$ & $\begin{array}{l}\text { Average } \\
\text { Particle } \\
\text { Size } \\
\text { Microns } \\
\end{array}$ \\
\hline \multicolumn{7}{|l|}{ Oxalate } \\
\hline $\mathrm{Pu} 4+0$ & 560 & 5 & 39 & 1.42 & 2.03 & 1.9 \\
\hline $\mathrm{Pu} 5-2$ & 420 & 5 & 69 & 1.55 & 2.00 & 2.2 \\
\hline Pu9-3 & 760 & 30 & 4.45 & 1.85 & 3.56 & 1.2 \\
\hline $\mathrm{Pu} 38$ & 760 & 30 & 4.88 & 1.53 & 2.70 & 1.4 \\
\hline Pu27 & 760 & 30 & 5.83 & 1.85 & 3.09 & 2.2 \\
\hline \multicolumn{7}{|l|}{ Hydroxide } \\
\hline $78-38-A$ & 850 & 120 & 5.0 & $\Rightarrow$ & $\Rightarrow$ & $\Rightarrow$ \\
\hline $78-38-B$ & 850 & 120 & 22.2 & $\infty$ & $\infty$ & 0 \\
\hline $17-8-A$ & 850 & 120 & 5.7 & - & $=$ & $\therefore$ \\
\hline $17-8-B$ & 850 & 120 & 11.2 & $\infty$ & $\infty$ & 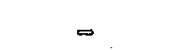 \\
\hline $78=46-A$ & 850 & 120 & 28.4 & 1.84 & 3.36 & 1.07 \\
\hline \multicolumn{7}{|l|}{ Peroxide } \\
\hline Pu29 & 490 & 30 & 26.0 & 2.79 & 4.96 & 2.27 \\
\hline Pu30 & 490 & 30 & 19.5 & 1.85 & 3.79 & 1.06 \\
\hline Pu31 & 490 & 30 & 23.7 & 2.10 & 4.14 & 1.22 \\
\hline
\end{tabular}


NUMEC $-2389-6$

\section{RESULTS AND DISCUSSION}

Pertinent sintering data are presented in Table III for compacts sintered under both reducing $\left(\mathrm{N}_{2}-6 \% \mathrm{H}_{2}\right)$ and oxidizing $\left(\mathrm{O}_{2}\right)$ conditions. Certain general conclusions can be drawn from these data. In agreement with previous investigations $(3,6)$, higher sintered densities were obtained with oxalate derived powder. Final densities of peliets produced from this material are more often in excess of $90 \%$ of theoretical $\mathrm{PuO}_{2}$ than is the case with hydroxide or peroxide derived material. The powders from nitrate ignition and metal oxidation sinter to relatively low density. It is to be noted that higher densities were generaliy obtained when sintering urider oxidizing conditions. This is to be anticipated since sintering under such conditions would prevent the formation of suboxides having lower theoretical density。 Gravimetric determinations made by reoxidation of reduction sintered pellets show that the final product is $\mathrm{PuO}_{1} 85$ to $\mathrm{PuO}_{1} .95$, which indicates a possible al pha $\mathrm{Pu}_{2} \mathrm{O}_{3}$ concentration in the range 10-40\%. Due to the lower density of alpham $\mathrm{Pu}_{2} \mathrm{O}_{3}$ one would $d_{2}$ therefore, expect the pellets sintered in an oxidizing atmosphere to have a $105 \%$ higher density than those sintered under redueing conditions. The data bear out this tendervey。

Typical microstructures of the reduction sintered compacts are shown in Figures 1 and 2。 The reduced second phase, alpha- $\mathrm{Pug}_{2} \mathrm{O}_{3}$ is readily diso tinguishable in all cases. No beta-Pu20 was detected by $x$ wray diffraction analysis. It is to be noted that the structure and location of the second phase material is dependent upon the presipitation route: the nature of the precursor, oxalate or hydroxide, obvioushy iniluenes the strocture of the final oxide product.

Sintering ads were investigated to improve sintered denstuty especially for

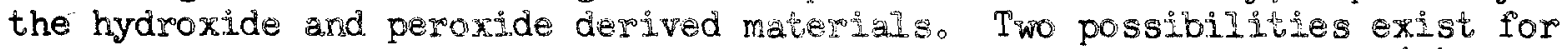
such an improvement of sintersilitity through impurity additions: (1) the impurity forms a reative Iiquid surrowding the grains at the sintering temperature, or (2) the impurity goes irto substitutional solid solution in the host 1attice. The suceess of the sold solution process depends on the relative cation sizes and the creation of lattice defects by the difference in valence states associated with the cationso

The first process, reactive liquid, has been obserped in the case of hydroxide derived material which had high impurity levels of $\mathrm{Fe}_{2} \mathrm{Cr}_{\mathrm{g}}$ and $\mathrm{Ni}$. $\mathrm{As}$ shown in Figure 2(a), a considerable liquid phase is observed along the grain bound. aries and this particular preparation (78,38-B) sintered to a higher density than the other hydroxide batches. For the solid solution process with $\mathrm{PuO}_{2}$ the selected cations should have an atomic radius olose to $0.93 \mathrm{~A}$ and be a stable mono-s dis, or tri-vilent specieso With this combination, such a solid solution would produce oxygen vacancies as the lattice defect and the oxygen mobility during sintering would then be enhanced. Extensive in vestigation $(7,8,9,10,11)$ of $\mathrm{Ca}^{+2}$ substituting for $\mathrm{Zr}^{+4}$ in the fluorite oxide 
NUNEC $-2389-6$

Table III

Sintering Chargeteristics of $\mathrm{PuO}_{2}$

(Sintered at $1600^{\circ} \mathrm{C}$ for 1 Hour in $\mathrm{N}_{2} 6 \% \mathrm{H}_{2}$ or $\mathrm{O}_{2}$ )

\begin{tabular}{|c|c|c|c|c|c|c|c|}
\hline \multirow{2}{*}{$\begin{array}{c}\text { Powder } \\
\text { Preparation } \\
\text { Route } \\
\end{array}$} & \multirow{2}{*}{$\begin{array}{c}\text { Batch } \\
\text { Designation }\end{array}$} & \multirow{2}{*}{$\begin{array}{c}\text { Compaction } \\
\text { Pressure } \\
\text { TSI } \\
\end{array}$} & \multirow{2}{*}{$\begin{array}{l}\text { Green } \\
\text { Density } \\
\text { gmles }\end{array}$} & \multicolumn{2}{|c|}{$\begin{array}{l}\text { Fired Density } \\
\mathrm{gm} / \mathrm{cc}\end{array}$} & \multicolumn{2}{|c|}{$\begin{array}{l}\text { Fired Density } \\
\text { Percent of } \\
\text { Theoretical } \mathrm{BuO}\end{array}$} \\
\hline & & & & $\mathrm{N}_{2}=6 \% \mathrm{H}_{2}$ & $\mathrm{O}_{2}$ & $\mathrm{~N}_{2}=6 \% \mathrm{H}_{2}$ & $\hat{O}_{2} 2$ \\
\hline Oxalate & $\begin{array}{l}\text { Pu } 4-4 \\
\text { Pu5-2 } \\
\text { Pu9-3 } \\
\text { Pu } 38 \\
\text { Pu27 } \\
\text { Pu27 }\end{array}$ & $\begin{array}{l}38 \\
38 \\
38 \\
40 \\
10 \\
20\end{array}$ & $\begin{array}{l}6.36 \\
5.85 \\
7.51 \\
7.25 \\
6.50 \\
7.01\end{array}$ & $\begin{array}{r}10.34 \\
10.35 \\
10.33 \\
9.58 \\
9.93 \\
10.21\end{array}$ & $\begin{array}{l}10.94 \\
10.90 \\
10.60 \\
10.55 \\
10.49 \\
10.70\end{array}$ & $\begin{array}{l}90.4 \\
90.5 \\
90.1 \\
83.6 \\
86.6 \\
89.1\end{array}$ & $\begin{array}{l}95.6 \\
95.2 \\
92.6 \\
92.1 \\
91.5 \\
93.4\end{array}$ \\
\hline Hydroxide & $\begin{array}{l}78-38-A \\
78-38-B \\
17-8-A \\
17-8-B \\
78-46-A\end{array}$ & $\begin{array}{l}32 \\
32 \\
32 \\
32 \\
32\end{array}$ & $\begin{array}{l}8.08 \\
5.95 \\
7.81 \\
6.90 \\
5.75\end{array}$ & $\begin{array}{r}9.94 \\
10.34 \\
9.50 \\
9.70 \\
10.36\end{array}$ & $\begin{array}{r}9.92 \\
10.71 \\
9.57 \\
9.85 \\
10.35\end{array}$ & $\begin{array}{l}86.7 \\
90.2 \\
82.9 \\
84.6 \\
90.4\end{array}$ & $\begin{array}{l}86.6 \\
93.5 \\
83.5 \\
85.9 \\
90.3\end{array}$ \\
\hline Peroxide & $\begin{array}{l}\text { Pu } 29 \\
\text { Pu } 29 \\
\text { Pu } 30 \\
\text { Pu } 30 \\
\text { Pu } 31 \\
\text { Pu } 31\end{array}$ & $\begin{array}{l}20 \\
40 \\
20 \\
40 \\
20 \\
40\end{array}$ & $\begin{array}{l}6.60 \\
7.04 \\
6.20 \\
6.73 \\
7.10 \\
7.57\end{array}$ & $\begin{array}{r}9.24 \\
9.26 \\
9.75 \\
10.28 \\
10.21 \\
10.12\end{array}$ & $\begin{array}{r}9.45 \\
9.87 \\
10.07 \\
10.51 \\
10.49 \\
10.71\end{array}$ & $\begin{array}{l}80.6 \\
80.8 \\
85.1 \\
89.7 \\
89.1 \\
88.3\end{array}$ & $\begin{array}{l}82.5 \\
86.1 \\
87.9 \\
91.7 \\
91.5 \\
93.4\end{array}$ \\
\hline Denitration & $\infty$ & 12 & 6.85 & 9.32 & 10.30 & 81.3 & 89.9 \\
\hline $\begin{array}{c}\text { Metal } \\
\text { Oxidation-Air }\end{array}$ & Pu.59A & 40 & 8.87 & 9.05 & 9.04 & 79.0 & 78.9 \\
\hline$\frac{\text { Metal }}{\text { Oxidation-Steam }}$ & Pus9B & 40 & 7.88 & 9.64 & 9.09 & 84.0 & 79.4 \\
\hline
\end{tabular}


NUMEC-2389-6

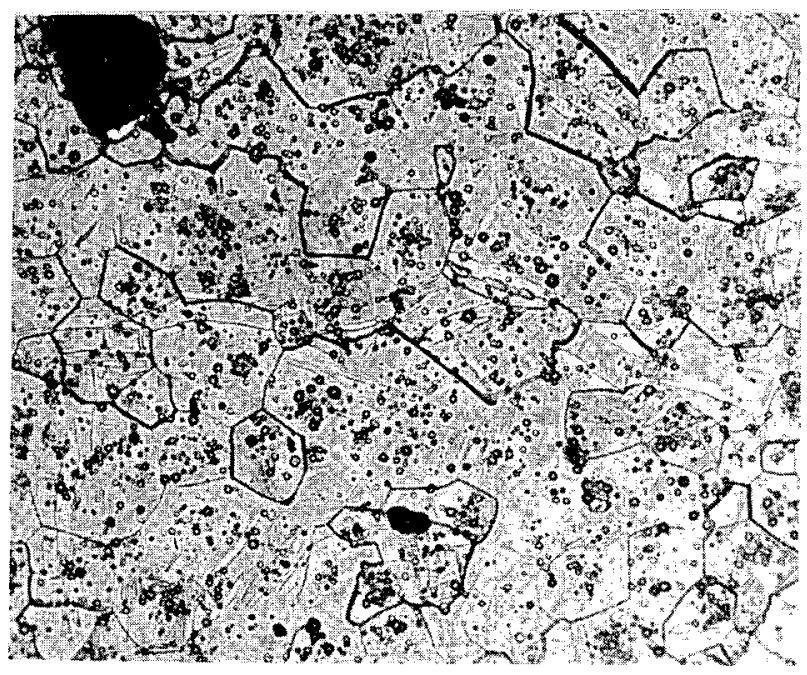

(a)

Pu 38

Sintered for 64 Hours

Neg. 891

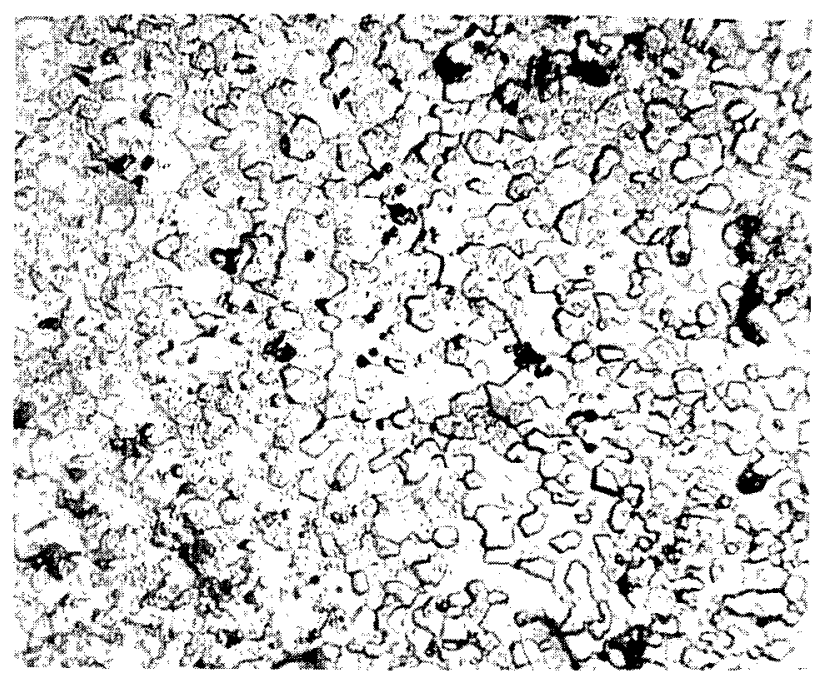

(b)

Pug-3

Sintered for 4 Hours

Neg. $3 x$

$400 x$

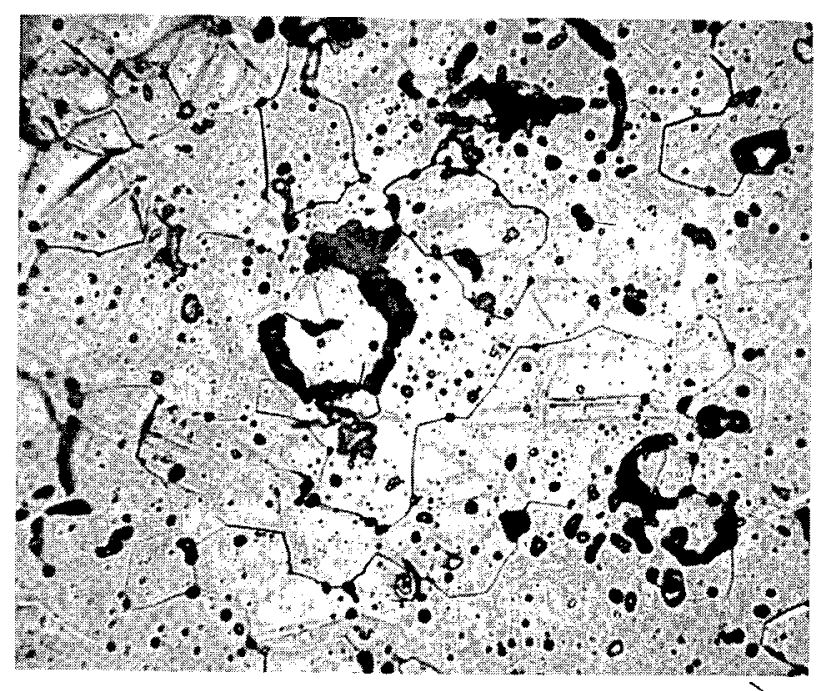

(c)

Pu4

Sintered for 1 Hour

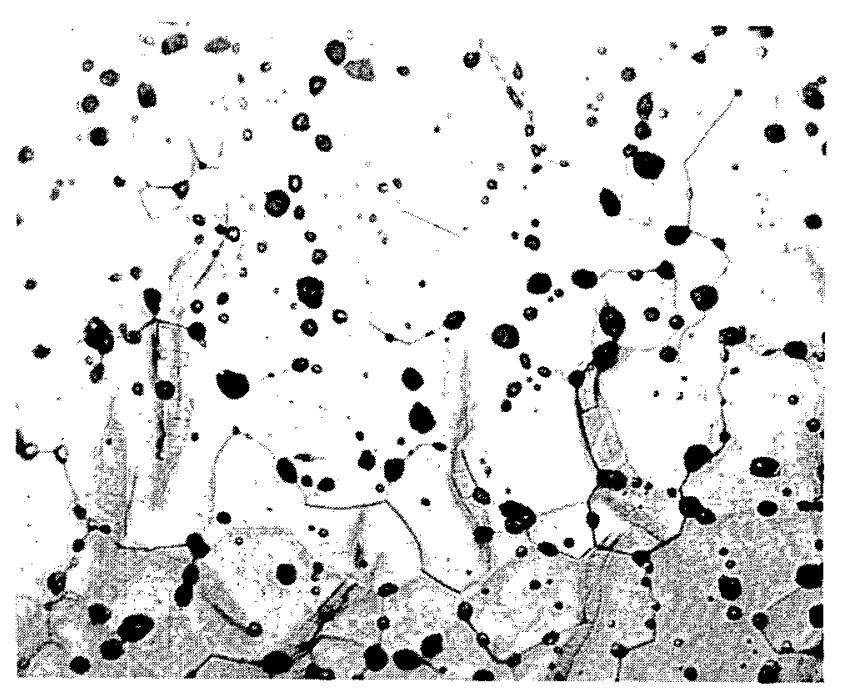

(d)

P124

Sintered for 1 Hour

Neg. 105

$400 \mathrm{x}$

Figure 1

Microstructures of $\mathrm{PuO}_{2}-0 \times a l a t e$ Derived

Sintered in Nitrogen-6\% Hydrogen at $1600^{\circ} \mathrm{C}$

Cathodic Vacuum Etched 


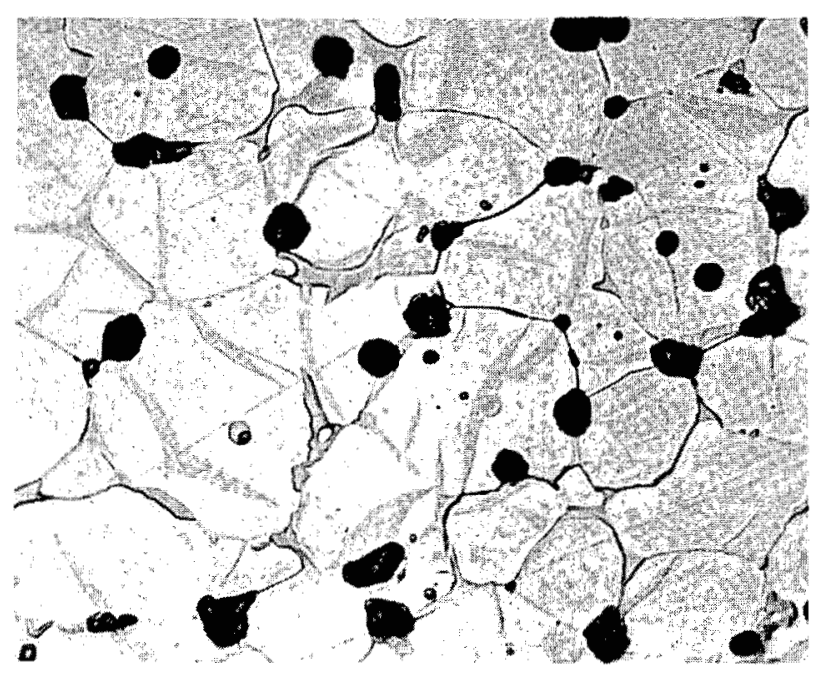

(a)

$73-38-3$

Neg. 328

$400 X$

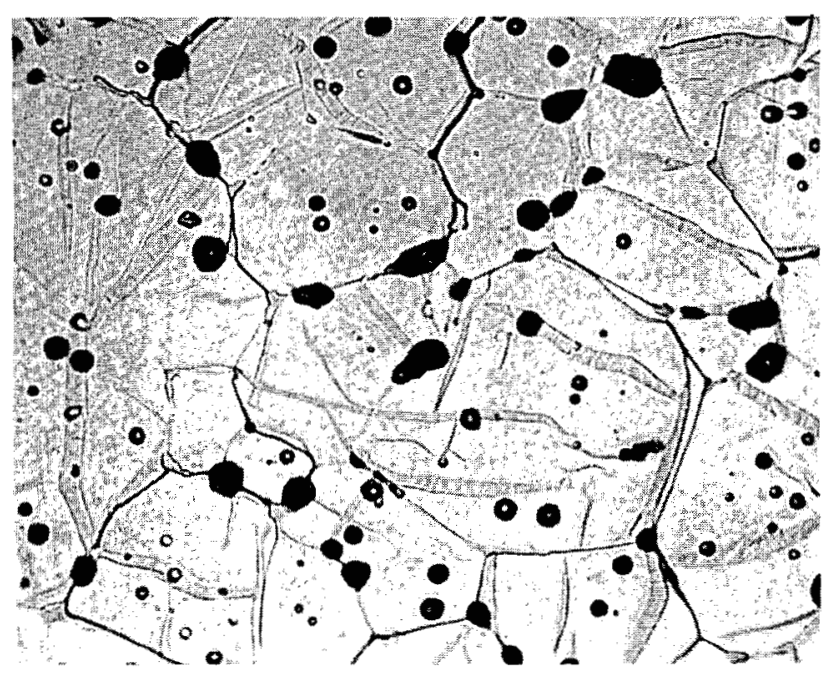

(b)

Neg. 330

$400 \mathrm{X}$

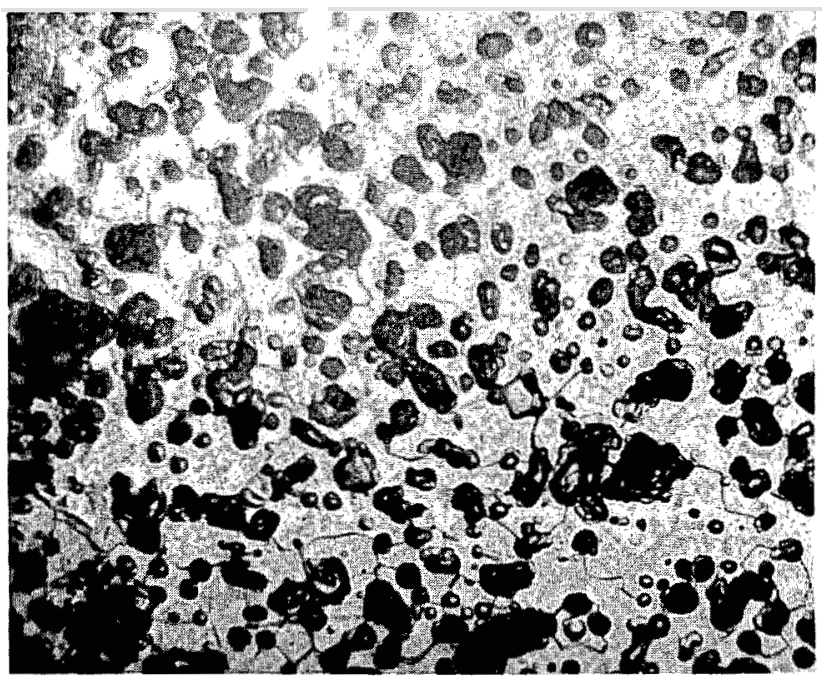

(d)

78-38-A

$17-8-A$

Neg. 331

$400 x$

Neg. 414

$400 \mathrm{X}$

Figure 2

Microstructures of $\mathrm{PuO}_{2}$ - Hydroxide Derived

Sintered in Nitrogen-6\% Hydrogen at $1600^{\circ} \mathrm{C}$ for 1 Hour

Cathodic Vacuum Etched 
has shown that the oxygen vacancy concentration is strictly controlled by composition. - The sintering behavior of $\mathrm{ThO}_{2}$ with $\mathrm{Ca}^{+2}$ substitution has been studied (12), and sintered densities in exeess of $98 \%$ theoretical were obtained in this manner. With $\mathrm{PuO}_{2}$, the cations which were selected along with their associated characteristics are shown in Table IV. Strontium and magnesium were added as the earbonate, yttrium as $\mathrm{Y}_{2} \mathrm{O}_{3}$, and calcium as $\mathrm{CaF}_{2}$ 。

The results of sintering trials involwing the use of controlled impurity additions are presented in Tables $V_{0} V I_{9}$ and VII. From these data, it is seen that strontium additions have a marked beneficial effect upon the sintering behavior in oxygen while the other adaitions lead to an equivalent or lower density. Improvement is noted only under oxidiuging sintering conditions, as expected, since the formation of oxygen vacancies, as such, could not be expected under reducing conditions. The situationg witen a reducing atmosphere is utilized, becomes further complicated by the behavior of the impurity como pound and by the formation of tiolvart plutonium. The beneficial atect of SxO is illustrated in Figure 3. Both the physical density relationship, percent of theoretical $\mathrm{PuO}_{2}+\mathrm{SrO}$ density for the mixture, and the PuO density relation ship, 1 pereent of theoretieal density of PuO 2 are shown. The physical density of a $\mathrm{PuO}_{2}$ preparation (Pu29) which sintered to a rather low density (83\%), without additives, was increased by $10 \%$ with $1.29 \mathrm{~m} / 0$ strontium addition. With a more sinterable grade $\mathrm{PuO}_{2}$ the pereent density inerease was smaller but still significant. Mierostructure was also observed to be affected by the strontium addition as show in Figure 4 。

The extent and ase of solid solution formation between $\mathrm{Y}_{2} \mathrm{O}_{3}$ or $\mathrm{SrO}_{\mathrm{O}}$ and $\mathrm{PuO}_{2}$ can be ascertinined rom electrical resistivity measurements $s_{9}$ the results of which are presented in Figwre 5. With an addition of only two mol percent, SrO or $\mathrm{Y}_{2} \mathrm{O}_{3}$, the electrical resistivity at room temperature decreased four to six gropers of magnitude. Ir the analogows system of calcium substitution in $\mathrm{ZrO}_{2}(7)$, the resistivity at $1000^{\circ} \mathrm{C}$ decreased only slightly more than one order of magnitude with 12 mol percent impurity. The similarity in the resistivity relationship for both $\mathrm{SP}^{4} 2$ and $\mathrm{Y}^{+} \mathrm{s}$ in $\mathrm{PuO}_{2}$ is expected since for an equivalent molas addition of eah oxides the same number of oxygen vacancies are formed. Actual differences in values for a specific impurity level are probably insignificant since that much difference has been obserwed in the unaltered $\mathrm{PuO}_{2}$ material.

The empirical pesults or enhancements of sinterability with concurrent decrease in electrical resistivity as $\mathrm{SrO}$ is added to $\mathrm{PuO}_{2}$ allow one to conjecture about the basic processes.

For example, the controlled strontium addition can enter the $\mathrm{PuO}_{2}$ fluorite lattice either substitutionally by pelacing a plutonium ion at a nornal cation site or interstitially by filling in normal vacant site. The second case involving interstitial cations has not been observed with other impurities in fluorite structured oxides $(8,10,13)$ and is most likely precluded by the energy relationship to form and mintain such an arrangemento While an increase 
NUMEC-2389-6

Table IV

Properties of Selected Cations

\begin{tabular}{lcccc} 
Element & $\begin{array}{c}\text { Valence } \\
\text { State }\end{array}$ & $\begin{array}{c}\text { Ionic } \\
\text { Ragius }\end{array}$ & $\begin{array}{c}\text { Thermal Neutron } \\
\text { Cross-Section } \\
\text { Barns }\end{array}$ & $\begin{array}{c}\text { Melting Point } \\
\text { of Oxide } \\
\text { oC }\end{array}$ \\
\cline { 2 - 4 } $\mathrm{Pu}$ & +3 & 1.08 & 270 & 2085 \\
$\mathrm{Pu}$ & +4 & 0.93 & 270 & 2400 \\
$\mathrm{Ca}$ & +2 & 0.99 & 0.43 & 2572 \\
$\mathrm{Sr}$ & +2 & 1.12 & 1.30 & 2430 \\
$\mathrm{Y}$ & +3 & 0.92 & 1.30 & 2410 \\
$\mathrm{Mg}$ & +2 & 0.67 & 0.06 & 2800
\end{tabular}


NUMEC - $2389-6$

\section{Table V \\ Effect of Various Impurities on Sintering Behavior of $\mathrm{PuO}_{2}$ \\ (Compacted at 20 TSI) \\ (Sintered at $1600^{\circ} \mathrm{C}$ for 1 Hour in $0_{2}$ )}

$\begin{array}{cccccc}\text { Composition } & \begin{array}{c}\text { Impurity } \\ \text { Addition }\end{array} & \begin{array}{c}\text { Impurity } \\ \text { Content } \\ \text { m/o }\end{array} & \begin{array}{c}\text { Green } \\ \text { Density } \\ \text { gm/ce }\end{array} & \begin{array}{c}\text { Fired } \\ \text { Density } \\ \text { sm/ce }\end{array} & \begin{array}{c}\text { Fired Density } \\ \text { Percent of }\end{array} \\ \text { (Hydroxide) } & - & 0 & 6.58 & 9.54 & 83.2 \\ & \mathrm{Sr0} & 1.29 & 6.57 & 10.62 & 93.4 \\ & \mathrm{C} 20 & 2.37 & 6.55 & 8.97 & 79.6 \\ & \mathrm{Mg0} & 3.27 & 6.49 & 9.18 & 82.0 \\ & \mathrm{CaF}_{2} & 1.71 & 6.59 & 9.03 & 79.8\end{array}$


Table VI

\section{Effect of SrO Additions on Sintering \\ Behavior of $\mathrm{PuO}$ \\ (Compacted at 40 TSI) \\ (Sintered at $1600^{\circ} \mathrm{C}$ for 1 Hour)}

\begin{tabular}{|c|c|c|c|c|c|c|c|}
\hline \multirow[b]{2}{*}{$\begin{array}{l}\text { Composition } \\
\text { Sro Content } \\
\text { in mol/o } \\
\end{array}$} & \multirow[b]{2}{*}{$\begin{array}{l}\text { Green } \\
\text { Density } \\
\text { gm/ce }\end{array}$} & \multicolumn{3}{|c|}{$\begin{array}{c}\text { Flowing Oxygen Atmo sphere } \\
\text { Fired Density } \\
\end{array}$} & \multicolumn{3}{|c|}{$\begin{array}{c}\text { Nitrogen-6\% Hydrogen Atmosphere } \\
\text { Fired Density } \\
\end{array}$} \\
\hline & & $\mathrm{em} / \mathrm{cec}$ & $\begin{array}{l}\text { Percent of } \\
\text { Theoretical } \\
\text { PuO } 2+\text { Sro Density }\end{array}$ & $\begin{array}{l}\text { Percent of } \\
\text { Theoretical } \\
\text { Puo } 2 \text { Density }\end{array}$ & $\mathrm{gm} / \mathrm{cc}$ & $\begin{array}{l}\text { Percent of } \\
\text { Theoretical } \\
\text { PuO } 2+\text { Sro Density }\end{array}$ & $\begin{array}{l}\text { Percent of } \\
\text { Theoretical } \\
\text { Pu0 } \\
\text { 2 Density }\end{array}$ \\
\hline $\begin{array}{l}\text { Pu29=0, } \\
\text { Pu29-1.29 }\end{array}$ & $\begin{array}{l}6.58 \\
6.57\end{array}$ & $\begin{array}{r}9.54 \\
10.62\end{array}$ & $\begin{array}{l}83.2 \\
93.4\end{array}$ & $\begin{array}{l}83.2 \\
92.1\end{array}$ & $\begin{array}{l}10.07 \\
10.23\end{array}$ & $\begin{array}{l}87.9 \\
89.9\end{array}$ & $\begin{array}{l}87.9 \\
88.7\end{array}$ \\
\hline $\begin{array}{l}\text { Pu } 30=0 \\
\text { Pu } 30-1.29\end{array}$ & $\begin{array}{l}6.73 \\
6.72\end{array}$ & $\begin{array}{l}10.51 \\
10.95\end{array}$ & $\begin{array}{l}91.7 \\
96.3\end{array}$ & $\begin{array}{l}91.7 \\
95.0\end{array}$ & 10.28 & $\begin{array}{l}89.7 \\
-\end{array}$ & $\begin{array}{c}89.7 \\
-\end{array}$ \\
\hline $\begin{array}{l}\text { Pu38-0 } \\
\text { Pu38-0.4 } \\
\text { Pu 38-0.8 } \\
\text { Pu38-1.29 } \\
\text { Pu 38-2.55 } \\
\text { Pu38-3.78 } \\
\text { Pu38-4.97 }\end{array}$ & $\begin{array}{l}7.25 \\
7.27 \\
7.24 \\
7.25 \\
7.21 \\
7.03 \\
6.96\end{array}$ & $\begin{array}{l}10.55 \\
11.06 \\
11.02 \\
10.95 \\
10.70 \\
10.57 \\
10.33\end{array}$ & $\begin{array}{l}92.1 \\
96 . ? \\
96.6 \\
96.3 \\
94 . ? \\
94.2 \\
92 . ?\end{array}$ & $\begin{array}{l}92.1 \\
96.3 \\
95.8 \\
95.0 \\
92.3 \\
90.7 \\
88.1\end{array}$ & $\begin{array}{c}9.58 \\
- \\
0 \\
10.23 \\
9.27 \\
9.77 \\
9.41\end{array}$ & $\begin{array}{c}83.6 \\
= \\
89.9 \\
82.1 \\
87.1 \\
84.5\end{array}$ & $\begin{array}{l}83.6 \\
- \\
8 \overline{8} .8 \\
80.0 \\
83.8 \\
80.3\end{array}$ \\
\hline
\end{tabular}


NUMEC-2389-6

\section{Table VII}

Effect of $\mathrm{Y}_{2} \mathrm{O}_{3}$ Additions on Sintering

Behavior of $\mathrm{PuO}_{2}$

(Compacted at $40 \mathrm{TSI}$ )

(Sintered at $1600^{\circ} \mathrm{C}$ for 1 Hour in $\mathrm{O}_{2}$ )

\begin{tabular}{|c|c|c|c|c|c|}
\hline Composition & $\begin{array}{l}\mathrm{Y}_{2} \mathrm{O}_{3} \\
\text { Content } \\
\mathrm{m} / \mathrm{o} \\
\end{array}$ & $\begin{array}{l}\text { Green } \\
\text { Density } \\
\mathrm{gm} / \mathrm{cc} \\
\end{array}$ & $\begin{array}{l}\text { Fired } \\
\text { Density } \\
\text { gm/cc } \\
\end{array}$ & $\begin{array}{l}\text { Fired Density } \\
\text { Percent of } \\
\text { Theoretical } \mathrm{PuO}_{2}\end{array}$ & $\begin{array}{l}\text { Electrical } \\
\text { Resistivity } \\
\text { ohm-cm } \\
\end{array}$ \\
\hline $\begin{array}{c}\text { Pu38 } \\
\text { (Oxalate) }\end{array}$ & $\begin{array}{l}0 \\
0.5 \\
1.0 \\
1.5 \\
2.0\end{array}$ & $\begin{array}{l}7.32 \\
7.40 \\
7.31 \\
7.31 \\
7.37\end{array}$ & $\begin{array}{l}10.69 \\
10.69 \\
10.65 \\
10.55 \\
10.43\end{array}$ & $\begin{array}{l}93.3 \\
93.6 \\
93.5 \\
93.0 \\
93.0\end{array}$ & $\begin{array}{l}1.77 \times 10^{6} \\
1.35 \times 10^{4} \\
1.29 \times 10^{3} \\
6.35 \times 10^{2} \\
3.80 \times 10^{2}\end{array}$ \\
\hline
\end{tabular}



PROPERTIES OF $\mathrm{PUO}_{2}$

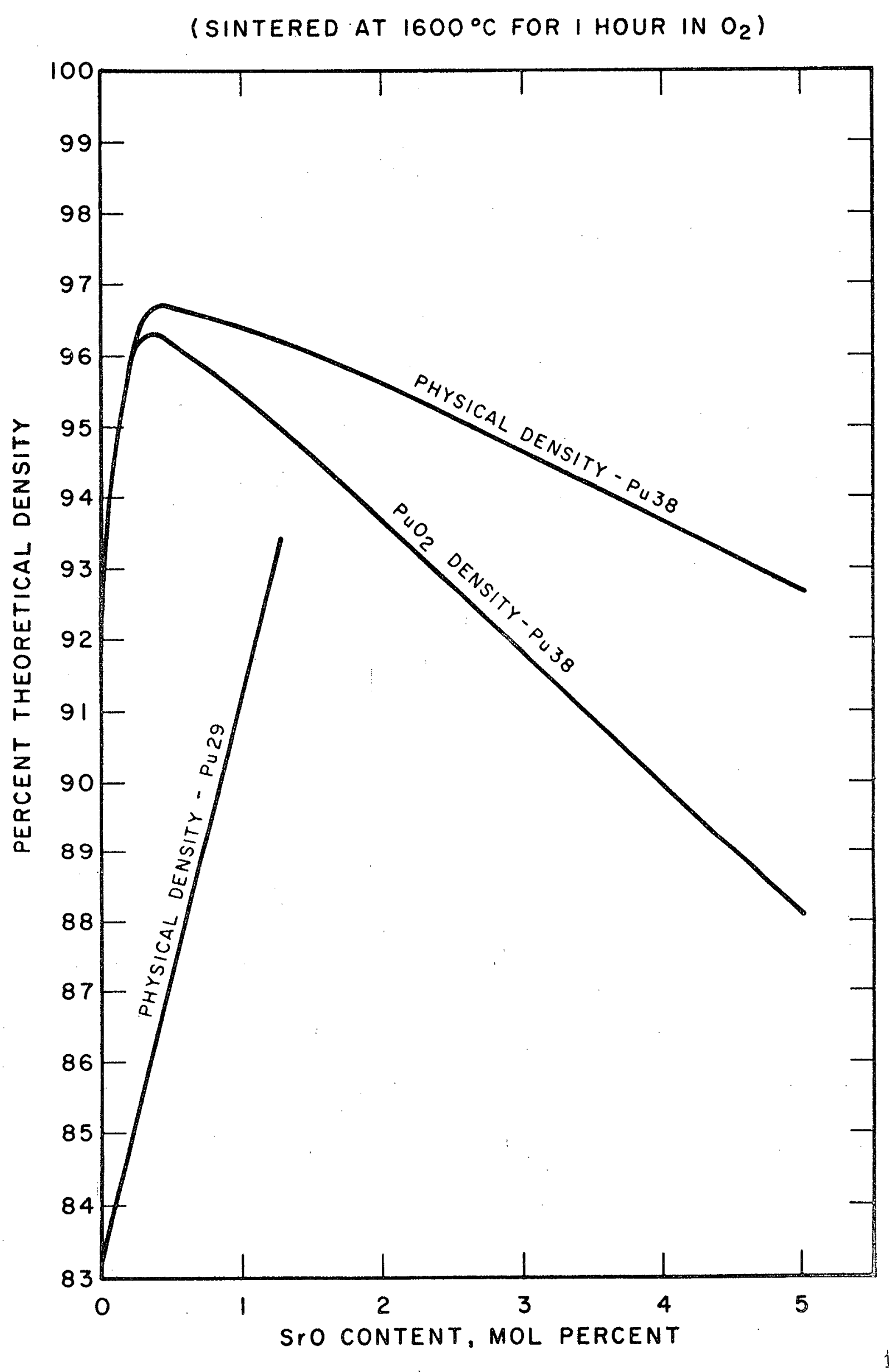

Figure 3 
EFFECT OF SRO ADDITION ON SINTERED PROPERTIES OF $\mathrm{PUO}_{2}$

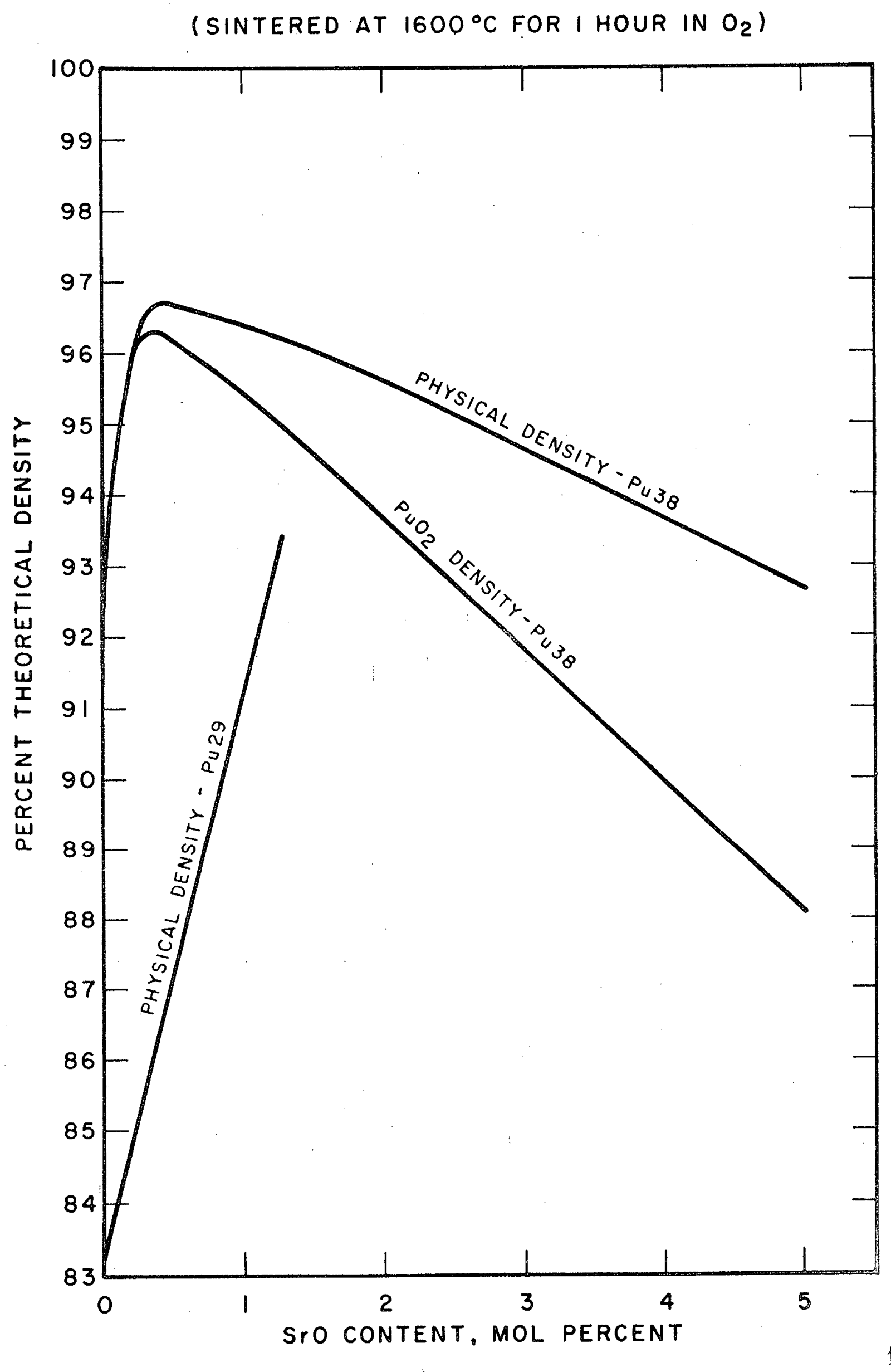

Figure 3 
NUMEC-2389-6

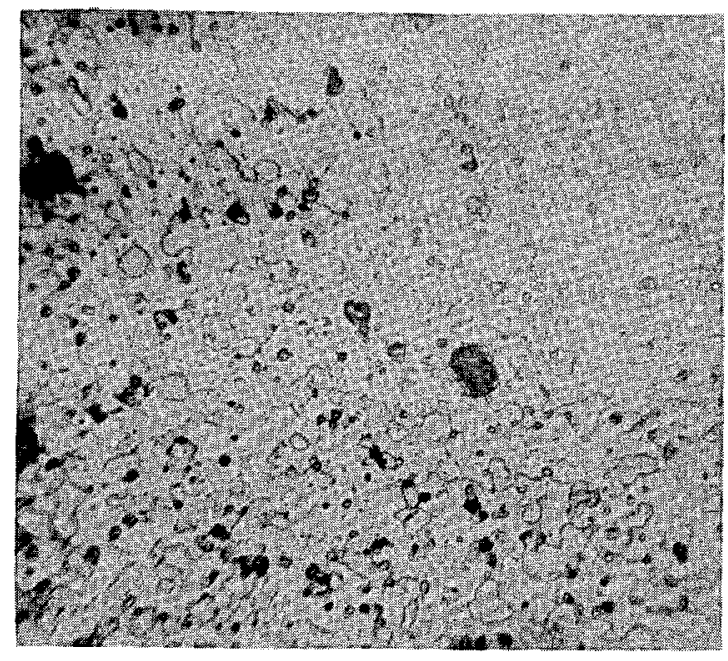

$$
\mathrm{PuO}_{2}-0.4 \mathrm{M} / \mathrm{O} \mathrm{SrO}
$$

Neg. 852

$400 \mathrm{X}$
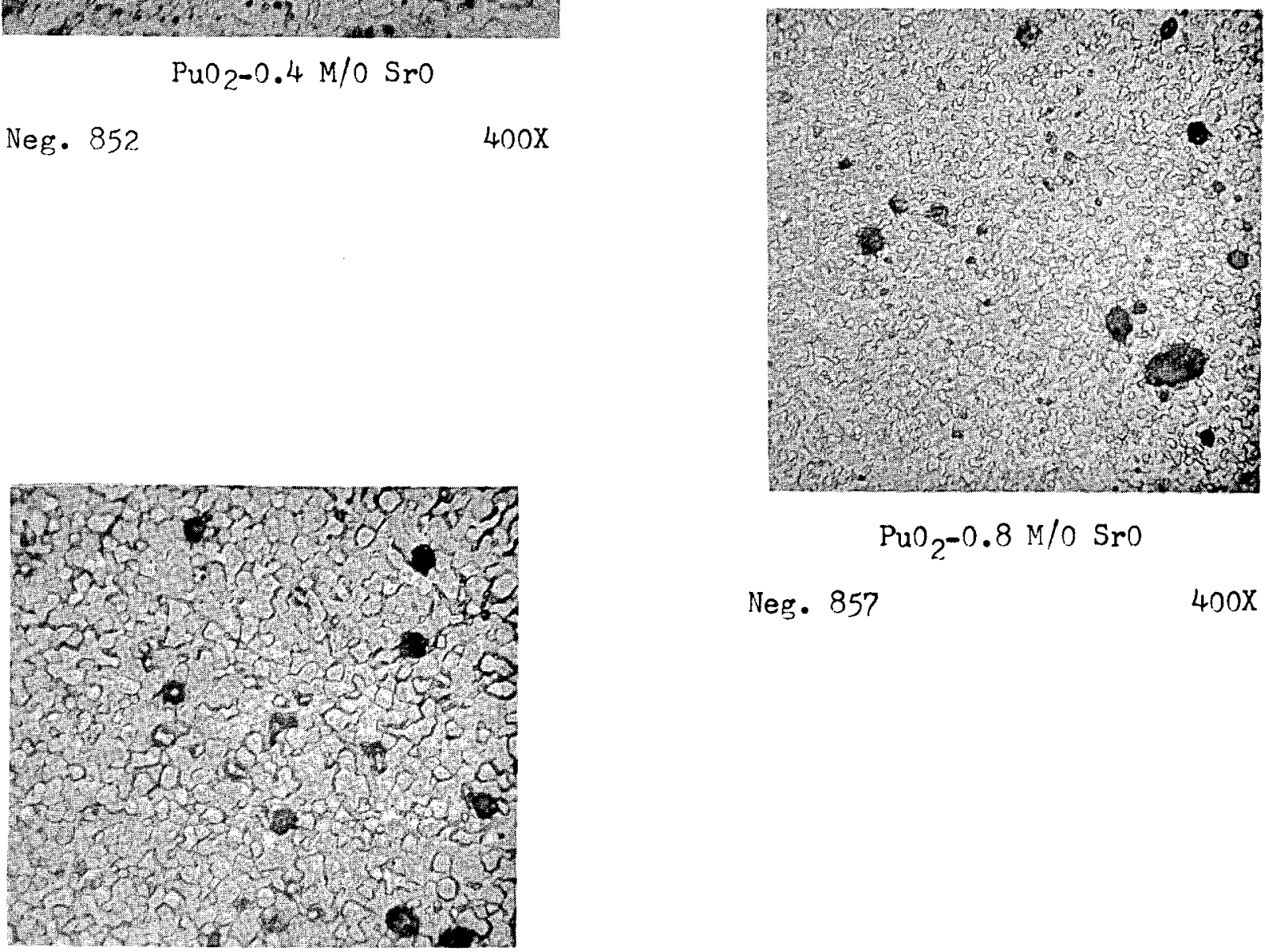

$$
\mathrm{PuO}_{2}-0.8 \mathrm{M} / \mathrm{O} \mathrm{SrO}
$$

Neg. 857

$400 \mathrm{X}$

$$
\mathrm{PuO}_{2}-1.29 \mathrm{M} / 0 \text { SrO }
$$

Neg. 862

$400 X$

Figure 4

Microstructures of $\mathrm{PuO}_{2}$ with $\mathrm{SrO}$ Additions

Sintered at $1600^{\circ} \mathrm{C}$ in Oxygen for 1 Hour Cathodic Vacuum Etched 
ELECTRICAL RESISTIVITY VS IMPURITY CONTENT

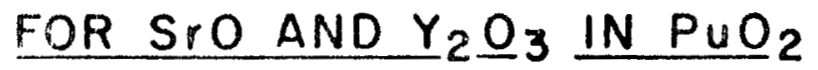

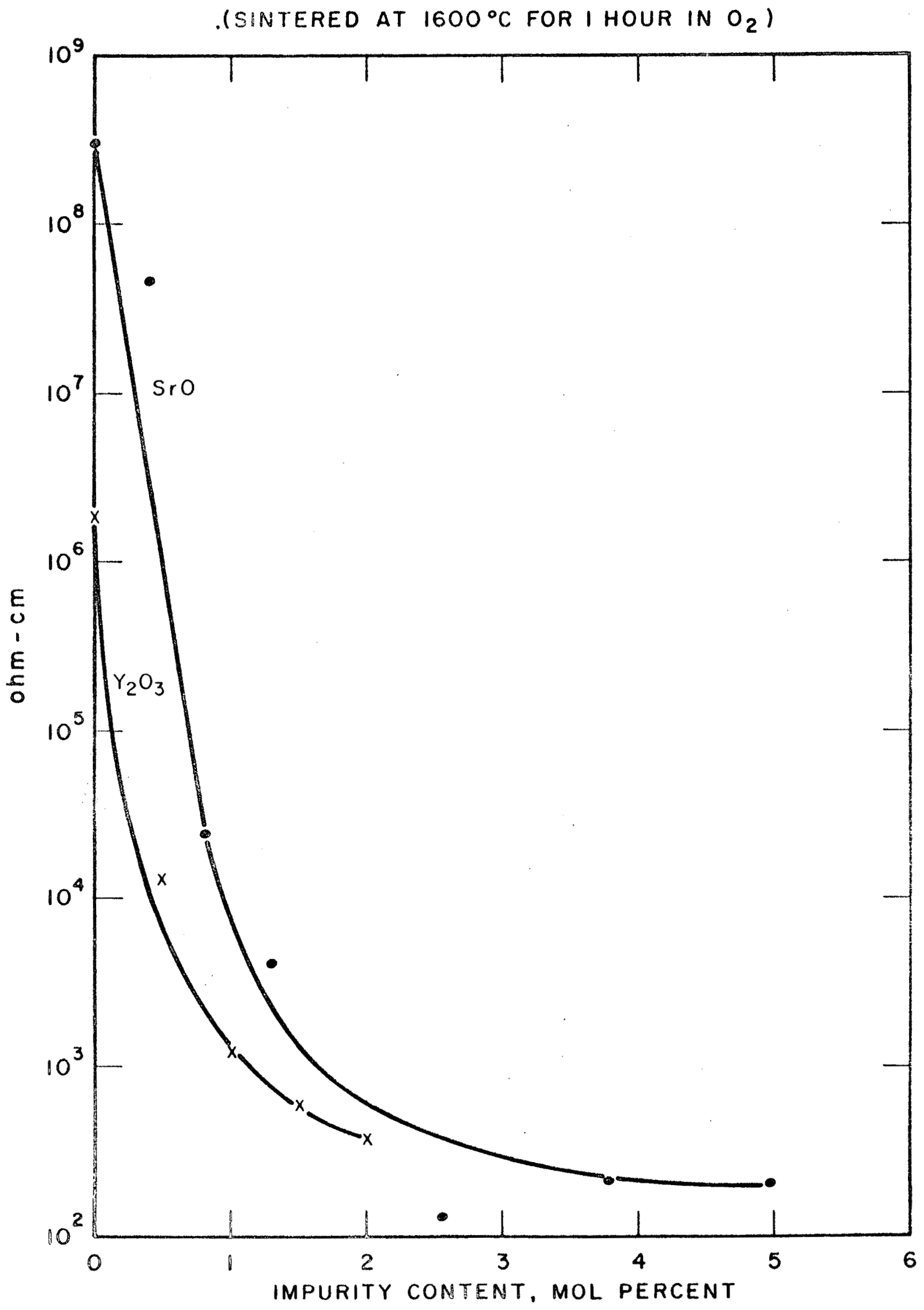

Figure 5 
in the lattice density and a decrease in electrical resistivity would be expected in the interstitial model, a mode for increasing sintered density would be difficult to visualize. On the other hand, the substitutional model can be utilized to satisfactorily explain the observed behavior but it in itself could have two configurations. The more logical of these is the formation of oxygen vacancies according to the general formula, $\mathrm{Sr}_{\mathrm{x}}^{+2} \mathrm{Pu}_{1-\mathrm{x}^{+}}^{+} \mathrm{O}_{2-\mathrm{x}^{\circ}}$ The electrical resistivity would decrease by changes in the conduction mechanism and the sintering behavior would be enhanced by the increased oxygen mobility due to the formation of the oxygen vacancies. One should not assume that the conduetion is entirely ionic in nature since there appears to be a considerabie difference in the resistivity value for the controlled impurity material, 103 onm om for $\mathrm{Sr}_{002} \mathrm{Pr}, 980_{1.98}$ as compared to reported $(14)$ values for reduced $\mathrm{PuO}_{2}$ of $105 \mathrm{ohm}-\mathrm{om}$ for $\mathrm{PuO}_{1.72}$ to $10^{8}$ ohmocm for $\mathrm{PuO}_{1.96}$. If anything the reduced phases should have a lower resistivity based on the existence of oxygen vacancies and $\mathrm{Pu}^{+} 3$ species. The other possibility for the substitutional case involves the formation of $\mathrm{Pu}$ t6 to maintain the electronneutrality of the lattice, resulting

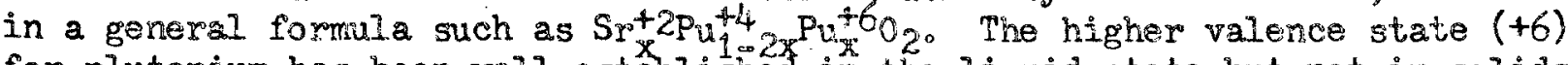
for plutonium has been well established in the liquid state but not in solids. The formation of such a mixed valence state would certainly give rise to a decrease in the electrical resistivity but would offer little reason for improvement in sinterability。 One particular aspect associated with the sintering behavior which should not be overlooked is the dynamic situation occurring at the sintering temperature between the individual oxides duing solid solution formation. Enhanced sintering may or may not be observed with preformed solid solution material. Without more specific knowledge, the most logieal explanation for both the dacrease in electrical resistivity and the improvement in sinterability with the impurity additions is the substitutional solid solution model with essociated formation of oxygen vacancies. 
NUMEC -2389-6

\section{SUMMARY AND CONCLUSIONS}

1. Plutonium dioxide, $\mathrm{PuO}_{2}$, made via $\mathrm{Pu}=\mathrm{IV}$ oxalate precipitation and conversion appears to be the most sinterable powder.

2. Higher $\mathrm{PuO}_{2}$ densities are obtained by sintering under oxidizing conditions. Most of the observed increase over reduction sintering is due to the elimination of lower density suboxides.

3. The microstructure of reduction sintered $\mathrm{PuO}_{2}$ is quite variable and the texture is more dependent upon the precipitation process than the sintering conditions.

4. Impurity additions of SrO in the range 0.4 to 1.0 mol percent increase the sintered densities by as much as $10 \%$. This is attributed to the formation of a solid solution with $\mathrm{Pu}_{2}$ in which oxygen vacancies were created. Electrical resistivity data indicate solid solution formation betweem $\mathrm{PuO}_{2}$ and both $\mathrm{I}_{2} \mathrm{O}_{3}$ and $\mathrm{SrO}_{0}$ 
NUMEC $-2389-6$

\section{ACKNOWLEDGEMENTS}

The author wishes to gratefully acknowledge Jerome Goodman for powder preparation, Joe Miles for metallography, and Jerome Roth for $x$-ray diffraction results. 
NUMEC $-2389-6$

\section{REFERENCES}

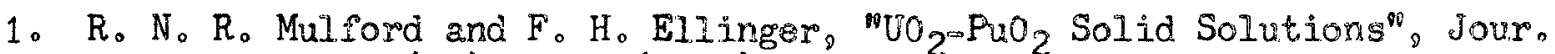
Am。Chem。Soc。(80), 2023 (1958)。

2. T. D. Chikalla, "Studies on the Oxides of Plutonium", pages $455-485$, Plutonium 1960, Cleaver.Hume Press Ltd., London.

3. Jo Do Lo Harrison, E。 Foster, and $L_{0}$ E。 Russell, "The Sintering Behavior of Mixed $\mathrm{VO}_{2}$ and $\mathrm{PuO}_{2}$ Fowders $_{2}{ }_{2}$ Fourth Plansee Seminar (1961).

4. L。E。 Russell, NoH。Brett, J。D。L。Harrison, and JoWilliams, "Observations on Phase Equilibria and Sintering Behavior in the $\mathrm{PuO}_{2} \mathrm{-UO}_{2}$ System", JoNuci。Material s (5), No。 2, 216-227 (1962)。

5. NoH. Brett and $L_{0} E_{0}$ RusselI, "The Simtering Behavior and Stability of ( $\left.\mathrm{Pu}_{0} \mathrm{U}\right)_{2}$ Solid Solutions", Trans, Brit. Cer。Soe。(62), No。 2, 97 (1963)。

6. A。BeI。 "Frittage Doxyde Douranium Et, De Plutonium", pages 449.455 , PIutonium 1960, CleaveroHume Press Ltd。, London.

7. F。 Trombe and MoFoex, "High Temperature Electrical Conductivity in the System $\mathrm{C}_{20} \mathrm{O}-\mathrm{ZrO}_{2}{ }^{20}$, Compto Rend。236, 1783 (1953)。

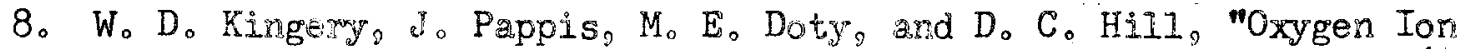

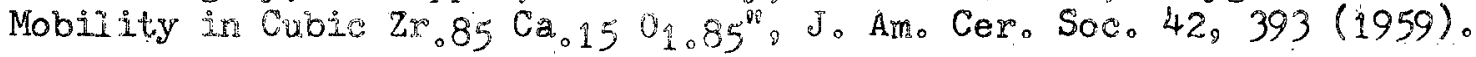

9. JoWeissbart and R。 J。Ruka, "Solld Electrolyte Fuel Cell", J。 Electrochem。Sos. 109,723 (1962)。

10. To Yo Tsen and E。 Co Subbaras, "X॰Fay and Electrical Conductivity Study

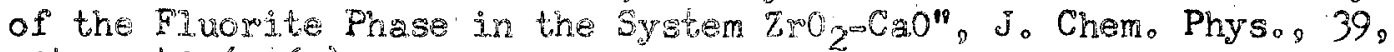
$1041-1047$ (1963)

11. E。 Co Subbara and $\mathrm{P}_{0} \mathrm{H}$ 。 Sutter, "OrderoDisorder and Ionic Conductivity

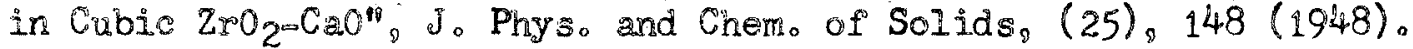

12. Jo $R_{0}$ Johnson and $C_{0} E_{0}$ Curtis, "Note on Sintering of Tho 2 ", J。Am。Cer。 Soc。 $(37), 611(1954)$ 。

13. JoBoWachtman, $\mathrm{JP}_{\circ}$, "Mechanical and Electrical Relaxation in $\mathrm{ThO}_{2}$ Containing Ca0 ${ }^{\circ}$, Phys。 Revo (131), $51 \%-2 \%$ (1963)。

14. CoE。 MeNeilly, "The Electrical Properties of PIutonium Oxides", Jo Nucl. Mat1so, (11), 53-58 (1964)。 


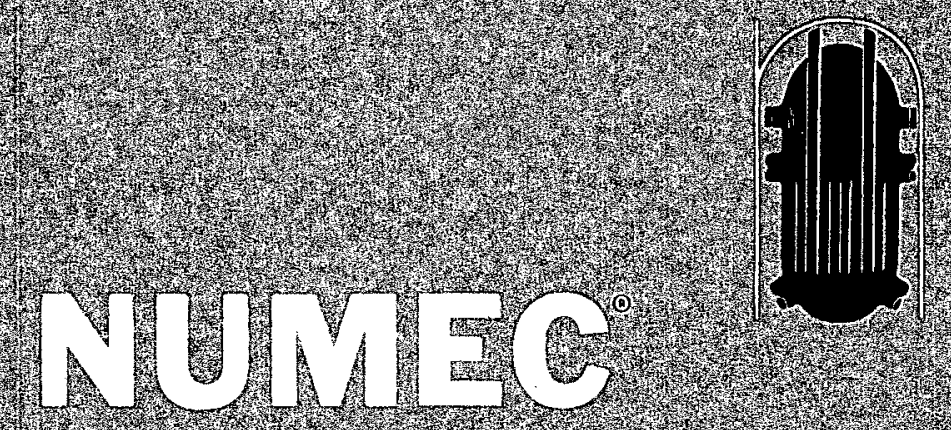

nuctear materials and equipment corporation apollo, pennsyluana 15613

cable NUMEC 